\title{
Cationic Polydiacetylene Micelles for Gene Delivery
}

\author{
Emmanuelle Morin, ${ }^{\neq, \dagger}$ Marc Nothisen, ${ }^{\dagger}$ Alain Wagner, ${ }^{*, \neq}$ and Jean-Serge Remy ${ }^{*,+}$ \\ ${ }^{\ddagger}$ Laboratory of Functional Chemo Systems and ${ }^{\dagger}$ Laboratory of Genetic Chemistry, CAMB, CNRS-UDS UMR 7199, \\ Faculté de Pharmacie, Université de Strasbourg, 74 route du Rhin, BP60024, 67401 Illkirch, France
}

Supporting Information

ABSTRACT: Cationic surfactants easily interact with plasmid DNA to form small lipoplexes. However, their detergent behavior and associated biological toxicity limit their use as gene delivery vectors. We have incorporated a diacetylene motif in the hydrophobic chain of cationic surfactants. By using UV irradiation, the small cationic micelles $(9 \mathrm{~nm})$ obtained with diacetylenic detergents were photopolymerized into $40 \mathrm{~nm}$ spheres. Electrostatic interactions with plasmid DNA led to the formation of $45 \mathrm{~nm}$ lipoplexes at $\mathrm{N} / \mathrm{P}=5$ ratio. In vitro transfection of the pCMV-Luciferase plasmid resulted in gene expression ( $>10^{10} \mathrm{RLU} / \mathrm{mg}$ protein $)$ at the same ratio, comparable with the commercially available JetSi-ENDO gene delivery system. This new and versatile class of molecules could lead to a new generation of in vivo gene delivery vectors.
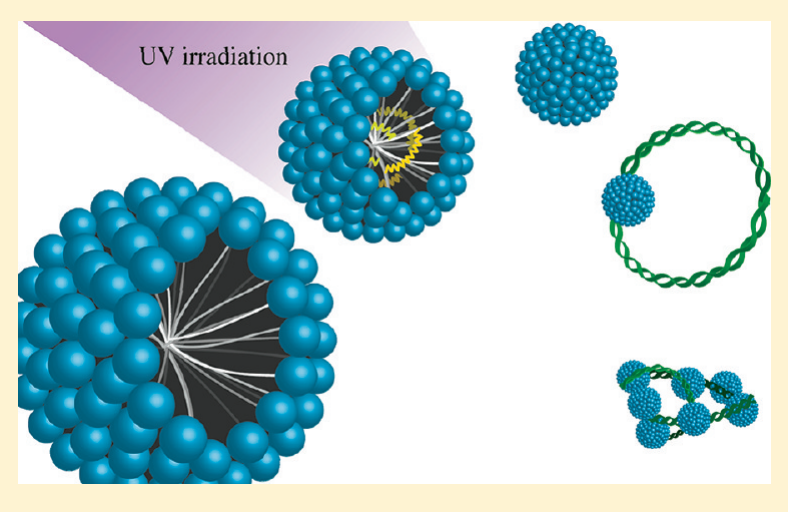

\section{INTRODUCTION}

Surfactants are a compound family, which show very interesting properties. Their amphiphilic nature allows them to selforganize and form various attractive supramolecular structures like micelles, liposomes, nanotubes, ${ }^{1}$ fibers, ${ }^{2}$ or more complex assemblies. $^{3-5}$ These cationic constructions have received a lot of attention, partly due to their use as synthetic supramolecular vectors for gene delivery. ${ }^{6-8}$ Ordered cationic liposomes or micelles or cationic detergents spontaneously form lipoplexes with DNA, due to electrostatic interactions between the cationic head groups of detergents and the negatively charged phosphate groups of nucleic acids. ${ }^{9-11}$ Among the large number of cationic amphiphiles, which induce effective gene transfer, amine- and ammoniumbased detergents are still the most studied. ${ }^{6,7}$ However, these organized structures have a very dynamic nature. Monomers constantly exchange between solution and self-assemblies, inducing instability and toxicity. Thus, it has been suggested that crosslinking, using amphiphiles bearing polymerizable groups, could improve the stability of these labile systems. ${ }^{12,13}$ Core cross-linked micelles and shell cross-linked micelles are usually obtained from copolymers and show some interesting properties in drug delivery. ${ }^{14,15}$ However, only a few studies describe the use of diacetylene micelles.

Diacetylene surfactants receive a lot of attention due to their polymerization properties upon exposition to ultraviolet radiations. ${ }^{16}$ This leads to the formation of more rigid structures and could also provide some new supramolecular nanoconstructs. ${ }^{17}$ The potential application range from biosensors, ${ }^{18,19}$ nonlinear optical devices ${ }^{20}$ through to drug delivery. ${ }^{21,22}$ It has been shown that diacetylene formulations ${ }^{23}$ or polymerized liposomes ${ }^{24}$ can deliver genes, but to the author's knowledge, few studies have been conducted on micelles.
In this paper, we describe the synthesis and the characterization of two new photopolymerized cationic micelles as synthetic DNA vectors. These new ammonium-based structures were obtained from the commercially available 10,12-pentacosadiyonic acid (PCDA) and could easily be photopolymerized. We demonstrate that these self-assemblies form lipoplexes in the presence of $\mathrm{pCMV}$-Luc plasmid and can efficiently mediate gene transfer. By comparing behaviors of polymerized and nonpolymerized DNA lipoplexes, we show that polymerization significantly improves transfection and reduces toxicity.

\section{EXPERIMENTAL PROCEDURES}

Synthesis of Pentacosa-10,12-diyn-1-ol (2). To a stirred suspension of lithium aluminum hydride $(0.91 \mathrm{~g}, 20.02 \mathrm{mmol})$ in THF (100 mL), a solution of 10,12-pentacosadiynoic acid (5.00 g, $13.34 \mathrm{mmol})$ in THF $(50 \mathrm{~mL})$ was added at $0{ }^{\circ} \mathrm{C}$ under $\mathrm{Ar}$ atmosphere. The resulting mixture was stirred for $90 \mathrm{~min}$ at RT. The reaction was quenched by adding $1 \mathrm{~N} \mathrm{HCl}$ solution $(25 \mathrm{~mL})$ and the mixture concentrated to dryness under reduced pressure. The aqueous layer was extracted with EtOAc $(2 \times 30 \mathrm{~mL})$, and the combined organic layers washed with $1 \mathrm{~N} \mathrm{HCl}(20 \mathrm{~mL})$, dried over anhydrous $\mathrm{Na}_{2} \mathrm{SO}_{4}$, filtered, and evaporated under vacuum to afford 2 as a white solid ( $4.40 \mathrm{~g}, 91 \%$ yield).

Synthesis of Pentacosa-10,12-diynyl-4-methylbenzenesulfonate (3). To a stirred solution of pentacosa-10,12-diyn-1ol $(4.40 \mathrm{~g}, 12.20 \mathrm{mmol})$ in $\mathrm{CH}_{2} \mathrm{Cl}_{2}(60 \mathrm{~mL})$ were successively added $p$-toluenesulfonyl chloride (3.49 g, $18.30 \mathrm{mmol})$,

Received: February 17, 2011

Revised: $\quad$ August 29, 2011 
triethylamine $(2.55 \mathrm{~mL}, 18.30 \mathrm{mmol})$, and catalytic amounts of DMAP. The resulting solution was stirred overnight at RT. A saturated solution of $\mathrm{NaHCO}_{3}(25 \mathrm{~mL})$ was added and the aqueous layer was extracted with $\mathrm{CH}_{2} \mathrm{Cl}_{2}(2 \times 15 \mathrm{~mL})$. The organic phases were combined, washed with a saturated solution of $\mathrm{NaCl}(15 \mathrm{~mL})$, dried over anhydrous $\mathrm{Na}_{2} \mathrm{SO}_{4}$, filtered, and concentrated under reduced pressure. The residue was submitted to silica-gel chromatography to afford compound $\mathbf{3}$ as a white solid ( $5.58 \mathrm{~g}$, 89\% yield).

Synthesis of $\mathrm{N}, \mathrm{N}$-Diethyl-pentacosa-10,12-diyn-1-amine (4). To a stirred solution of pentacosa-10,12-diynyl-4-methylbenzenesulfonate $(7.14 \mathrm{~g}, 13.86 \mathrm{mmol})$ and $\mathrm{Na}_{2} \mathrm{CO}_{3}(7.35 \mathrm{~g}$, $69.3 \mathrm{mmol})$ in $\mathrm{CH}_{3} \mathrm{CN}(150 \mathrm{~mL})$ was added diethylamine $(5.07 \mathrm{~g}, 69.3 \mathrm{mmol})$. The solution was stirred at $70^{\circ} \mathrm{C}$ for $24 \mathrm{~h}$. The solvent was removed under reduced pressure and the residue was poured into a saturated solution of $\mathrm{NaHCO}_{3}(60 \mathrm{~mL})$. The aqueous layer was extracted with $\mathrm{CH}_{2} \mathrm{Cl}_{2}(4 \times 25 \mathrm{~mL})$, and the organic layers were combined, washed with a saturated solution of $\mathrm{NaCl}(15 \mathrm{~mL})$, dried over anhydrous $\mathrm{Na}_{2} \mathrm{SO}_{4}$, filtered, and concentrated under reduced pressure. The residue was purified by silica-gel chromatography (eluting with EtOAc/cyclohexane $5: 95)$ to yield compound 4 as a colorless oil (3.54 g, 79\% yield).

Synthesis of 4-(2-Aminoethyl)-1,7-bis(tert-butoxycarbonyl)1,4,7-triazaheptane (6). To a stirred solution of tris(2-aminoethyl)amine $(1.47 \mathrm{~g}, 10.05 \mathrm{mmol})$ in THF $(40 \mathrm{~mL})$ at $0{ }^{\circ} \mathrm{C}$ was slowly added BocON ( $4.95 \mathrm{~g}, 20.11 \mathrm{mmol})$ in THF $(50 \mathrm{~mL})$. The solution was stirred overnight at RT. The solvent was removed under reduced pressure and the residue was poured into EtOAc $(50 \mathrm{~mL})$. The organic layer was washed with $\mathrm{NaOH} 1 \mathrm{M}(2 \times 10 \mathrm{~mL})$. The aqueous layer was diluted into a saturated solution of $\mathrm{NaCl}(20 \mathrm{~mL})$ and was extracted with EtOAc $(3 \times 10 \mathrm{~mL})$. The organic layers were combined, dried over anhydrous $\mathrm{Na}_{2} \mathrm{SO}_{4}$, filtered, and concentrated under reduced pressure. The residue was purified by silica-gel chromatography (eluting with $\mathrm{CH}_{2} \mathrm{Cl}_{2} /$ methanol 5:1) to yield compound $\mathbf{6}$ as a pale yellow oil ( $1.57 \mathrm{~g}, 45 \%$ yield).

Synthesis of Di-tert-butyl (((2-(tetracosa-10,12-diynamido)ethyl)azanediyl)bis(ethane-2,1-diyl))dicarbamate (7). To a stirred solution of 10,12-pentacosadiynoic acid $(1.00 \mathrm{~g}, 2.90 \mathrm{mmol})$ and $\mathrm{N}$-hydroxysuccinimide $(0.50 \mathrm{~g}, 4.33 \mathrm{mmol})$ in $\mathrm{CH}_{2} \mathrm{Cl}_{2}$ $(20 \mathrm{~mL})$ were added successively 1-ethyl-3-(3-dimethylaminopropyl) carbodiimide $(0.83 \mathrm{~g}, 4.33 \mathrm{mmol})$ and $N, N$-diisopropylethylamine $(757 \mu \mathrm{L}, 4.33 \mathrm{mmol})$. The solution was stirred overnight at RT. The solvent was removed under reduced pressure and the residue was poured into EtOAc $(20 \mathrm{~mL})$. The organic layer was washed with $\mathrm{H}_{2} \mathrm{O}(2 \times 10 \mathrm{~mL})$, dried over anhydrous $\mathrm{Na}_{2} \mathrm{SO}_{4}$, filtered, and concentrated under reduced pressure. The white solid was solubilized into THF $(50 \mathrm{~mL})$ with $\mathrm{Et}_{3} \mathrm{~N}(606 \mu \mathrm{L}$, $4.33 \mathrm{mmol}$ ) and 4-(2-aminoethyl)-1,7-bis(tert-butoxycarbonyl)1,4,7-triazaheptane 4 (1.08 g, $2.90 \mathrm{mmol})$, and the solution was stirred overnight at RT. The solvent was removed under reduced pressure, and the residue was purified by silica-gel chromatography (eluting with EtOAc) to yield compound 7 as a white solid $(1.57 \mathrm{~g}, 85 \%$ yield $)$.

Synthesis of $\mathrm{N}$-(2-(Bis(2-aminoethyl)amino)ethyl)tetracosa-10,12-diynamide (8). To a stirred solution of 7 (0.2 g, $0.28 \mathrm{mmol}))$ in $\mathrm{CH}_{2} \mathrm{Cl}_{2}(5 \mathrm{~mL})$ was added trifluoroacetic acid $(327 \mu \mathrm{L}, 4.27 \mathrm{mmol})$. The solution was stirred $4 \mathrm{~h}$ at RT. The solvent was removed under reduced pressure and the residue was poured into EtOAc $(10 \mathrm{~mL})$. The organic layer was washed with $\mathrm{NaOH} 1 \mathrm{M}(1 \times 10 \mathrm{~mL})$, dried over anhydrous $\mathrm{Na}_{2} \mathrm{SO}_{4}$, filtered, and concentrated under reduced pressure to yield compound $\mathbf{8}$ as a white solid ( $0.14 \mathrm{~g}$, quantitative).

Polymerization. For the photopolymerization steps, quartz cuvettes containing $3 \mathrm{~mL}$ of micelles solution were placed into a Cross-Linker Bio-Link 254 from Fischer Bioblock. Photopolymerization was achieved at $254 \mathrm{~nm}$ and $48 \mathrm{~W}$.

Photopolymerization was followed by UV-visible spectroscopy on a Varian Cary 100 Bio UV-visible spectrophotometer.

CMC Measurements. Surface tensions were measured by using the du Nouy ring, as follows. First, $15 \mathrm{~mL}$ of solution was prepared by diluting stock solutions of micelles. The solution were then transferred to the tensiometer vessel and was allowed to equilibrate at $25^{\circ} \mathrm{C}$ for $5 \mathrm{~min}$.

Dynamic Light Scattering (DLS). The hydrodynamic radii were determined via DLS measurements using a Malvern nano ZS apparatus with the following specifications: sampling time $=$ $90 \mathrm{~s}$; refractive index of medium, $0.1 \mathrm{M}$ acetate buffer = 1.340; phosphate buffer $=1.340$; refractive index of particles $(\mathrm{RI})=1.43$; medium viscosity $=1.0140 \mathrm{cP}$; temperature $=25^{\circ} \mathrm{C}$. Data were analyzed using multimodal number distribution software included with the instrument. $\zeta$ potentials were measured with the same apparatus and with the following specifications: 20 measurements per sample; dielectric constant $=80$; temperature $=$ $25^{\circ} \mathrm{C}$; beam mode $\mathrm{F}(\mathrm{Ka})=1.5$ (Smoluchowski model).

Transmission Electron Microscopy (TEM). Images were taken with a TEM Phillips CM12 apparatus, onto 300 mesh copper grids (Ted Pella, 822-F, Formvar removed). Ten microliters of sample was allowed to adsorb for $1 \mathrm{~min}$ onto grids. Grids were wicked from one side, and placed for $30 \mathrm{~s}$ on a $50 \mu \mathrm{L}$ drop of $2 \%$ uranyl acetate, wicked again, and air-dried before imaging.

Agarose Gel Electrophoresis. Twenty microliters of water containing $5 \%$ glucose or $150 \mathrm{mM} \mathrm{NaCl}, 0.4 \mu \mathrm{g} \mathrm{pCMV}$-Luc, and increasing amount of polymerized and nonpolymerized cationic micelles were subjected ( $30 \mathrm{~min}$ of complexation time) to electrophoresis in a $1 \%$ agarose gel containing $1 \mathrm{mM}$ EDTA, $40 \mathrm{mM}$ Tris acetate buffer, and $0.5 \mu \mathrm{g} / \mathrm{mL}$ ethidium bromide for $90 \mathrm{~min}$ at $100 \mathrm{~V}$. DNA was visualized with an UV transilluminator at $254 \mathrm{~nm}$.

Cell Culture. HeLa cells were grown in Eagle's MEM supplemented with $10 \% \mathrm{FBS}$, L-glutamine $(2 \mathrm{mM})$, penicillin (100 units $/ \mathrm{mL})$, and streptomycin $(100 \mu \mathrm{g} / \mathrm{mL})$. Cells were maintained at $37^{\circ} \mathrm{C}$ in a $5 \% \mathrm{CO}_{2}$ humidified atmosphere and all experiments were done in triplicates. The day before experiment, cells were seeded in 24-multiwell plates at $5 \times 10^{4}$ cells/well in fresh complete medium $(1 \mathrm{~mL})$.

Lipoplex Formation for PCMV-Luc Delivery. The procedure is for a 24-multiwell plate experiment. Typically, an aqueous solution of polymerized and nonpolymerized micelles of compound 4 and 8: $\mathbf{M}_{4} \mathbf{P}_{1 \mathrm{~h}}, \mathbf{M}_{4} \mathrm{NP}, \mathbf{M}_{8} \mathbf{P}_{1 \mathrm{~h}}$ and $\mathbf{M}_{8} \mathrm{NP}$ (volume depending on $\mathrm{N} / \mathrm{P}$ ratio), was diluted up to $50 \mu \mathrm{L}$ in water containing $5 \%$ glucose or $150 \mathrm{mM} \mathrm{NaCl}$. The solution was homogenized by vortexing and left for $10 \mathrm{~min}$. Separately, an aqueous solution of pCMV-Luc (corresponding to $2 \mu \mathrm{g}$ of pCMV-Luc) was diluted up to $50 \mu \mathrm{L}$ in water containing $5 \%$ glucose or $150 \mathrm{mM} \mathrm{NaCl}$. The solution was then homogenized and left for 10 min, after which the $\mathrm{M}_{4} \mathrm{P}_{1 \mathrm{~h}}, \mathrm{M}_{4} \mathrm{NP}, \mathrm{M}_{8} \mathrm{P}_{1 \mathrm{~h}}$, or $\mathrm{M}_{8} \mathrm{NP}$ solution was added to the pCMV-Luc solution, and vigorously mixed (15 s). Finally, lipoplexes were incubated for $30 \mathrm{~min}$ at RT and added in each well by diluting with serum free cell culture medium $(1 \mathrm{~mL})$. Four hours later, serum $(0.1 \mathrm{~mL} /$ well $)$ was added. The gene expression profiles were analyzed $24 \mathrm{~h}$ after addition of lipoplexes. Transfection assays were also performed in the presence 
Scheme 1. Synthesis of Amphiphile 4
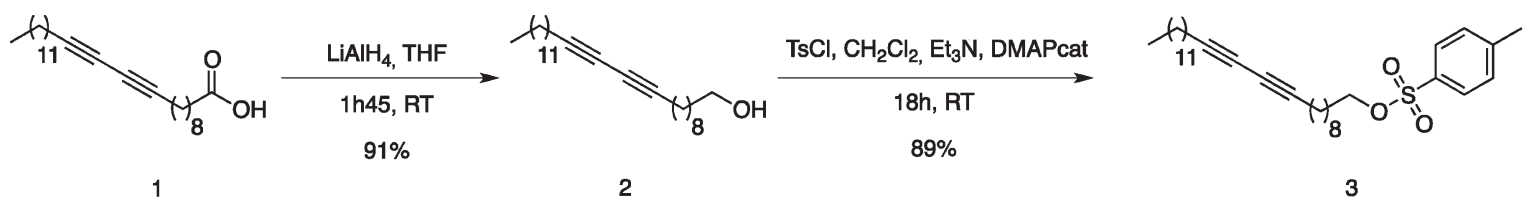

2

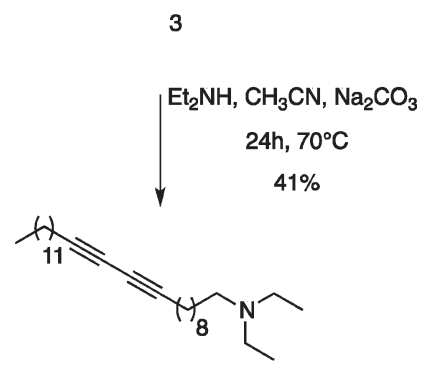

4

Scheme 2. Synthesis of Amphiphile 8

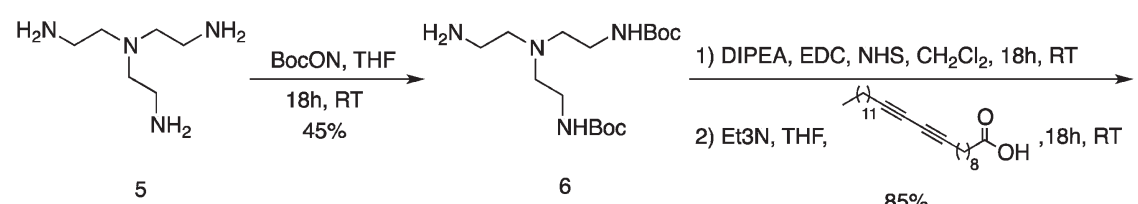

5
6
$85 \%$

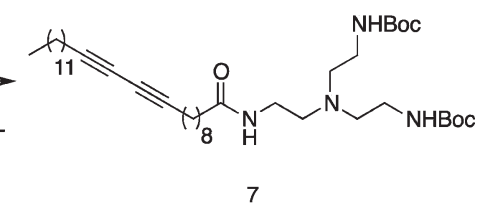

TFA, $\mathrm{CH}_{2} \mathrm{Cl}_{2}$ 24h, RT quant.

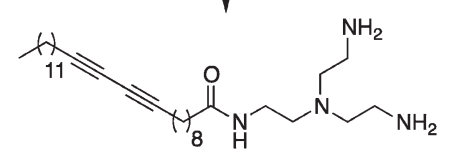

8 of serum: after incubation, lipoplexes were added in each well by diluting with complete cell culture medium (10\% serum, $1 \mathrm{~mL})$.

Quantification of the Luciferase Gene Expression. Luciferase gene expression was determined $24 \mathrm{~h}$ after delivery with a commercial kit, using manufacturer's protocol (Luciferase Assay System, Promega, Charbonnières, France). The luminescence was measured from $10 \mu \mathrm{L}$ of lysate during $1 \mathrm{~s}$ with a luminometer (Centro LB960 XS; Berthold, Thoiry, France). Luciferase activity is expressed as the mean of light units integrated over $10 \mathrm{~s}$ (RLU) and normalized per mg of cell protein by using the BCA assay (Pierce, Brebières, France). The errors bars represent standard deviation derived from triplicate experiments. JetPEI and JetSi-ENDO are transfection reagents (Polyplus-Transfection, Illkirch, France), used according to manufacturer's instructions.

\section{RESULTS}

Design and Synthesis. The two new ammonium-based amphiphiles were easily obtained from the commercially available acid 1. The synthesis of compound 4, as depicted in Scheme 1, was prepared in three steps as previously reported. ${ }^{3}$
BOC protection of the two terminal amines of tris (2-aminoethyl)amine affords compound 6 , which is easily coupled to the starting acid $\mathbf{1}$ as described in Scheme 2. Treatment of 7 with an excess of TFA provides a high yield of compound $\mathbf{8}$.

Micelle Characterization. Measurements of the surface tension of $\mathrm{M}_{4} \mathrm{NP}$ and $\mathrm{M}_{8} \mathrm{NP}$ solutions allowed us to access the critical micellar concentrations (CMC) of nonpolymerized solutions. Curves are presented in the Supporting Information. $\mathrm{M}_{4} \mathrm{NP}$ and $\mathrm{M}_{8} \mathrm{NP}$ solutions have $\mathrm{CMC}$ values of $12 \mu \mathrm{mol} / \mathrm{L}(0.0049 \mathrm{mg} / \mathrm{mL})$ and $21 \mu \mathrm{mol} / \mathrm{L},(0.011 \mathrm{mg} / \mathrm{mL})$, respectively. Following polymerization, CMC could not be detected anymore. The selfassembly of amphiphiles $\mathbf{4}$ and $\mathbf{8}$ into micelles was then assessed by DLS. Experiments with compound 4 at $600 \mu \mathrm{M}(0.25 \mathrm{mg} / \mathrm{mL})$ in various buffer solutions showed the importance of $\mathrm{pH}$ and medium composition. In $0.1 \mathrm{M}$ phosphate buffer $(\mathrm{pH}=7.4)$, we observed no micellar structures but $400 \mathrm{~nm}$ aggregates were observed, while in $0.1 \mathrm{M}$ acetate buffer $(\mathrm{pH}=5)$, amphiphile 4 led to the formation of nonpolymerized micelles $\left(\mathrm{M}_{4} \mathrm{NP}\right)$ of $9 \mathrm{~nm}$ diameter (see Supporting Information). Similarly, nonpolymerized micelles of compound $8\left(\mathrm{M}_{8}\right)$ at $500 \mu \mathrm{M}(0.25 \mathrm{mg} / \mathrm{mL})$ were only observed in $0.1 \mathrm{M}$ acetate buffer. Micelle formation and size were confirmed by transmission electron microscopy 

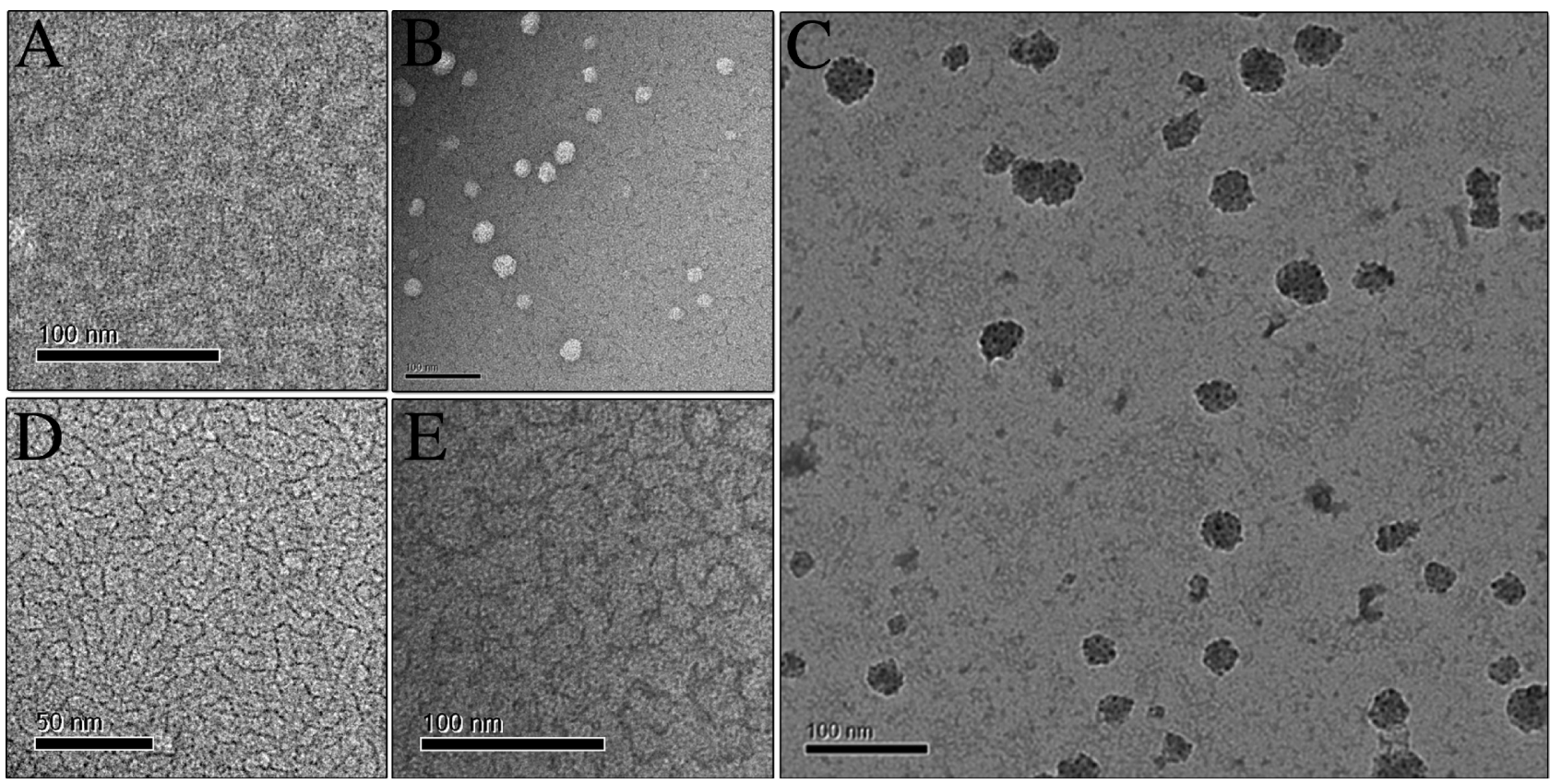

Figure 1. TEM images of $\mathrm{M}_{4}$ and $\mathrm{M}_{8}(\mathrm{C}=600 \mu \mathrm{M}$ and $500 \mu \mathrm{M}$, respectively $)$ in $0.1 \mathrm{M}$ acetate buffer. $\mathrm{A}, \mathrm{M}_{4} \mathrm{NP} ; \mathrm{B}, \mathrm{M}_{4} \mathrm{P}_{1 \mathrm{~h}} ; \mathrm{C}, \mathrm{M}_{4} \mathrm{P}_{1 \mathrm{~h}}$ diluted to $60 \mu \mathrm{M}$ in phosphate buffer; D, $\mathrm{M}_{8} \mathrm{NP} ; \mathrm{E}, \mathrm{M}_{8} \mathrm{P}_{1 \mathrm{~h}}$. Scale bars: $100 \mathrm{~nm}$ (A, B, C, and E) and $50 \mathrm{~nm}(\mathrm{D})$.

A

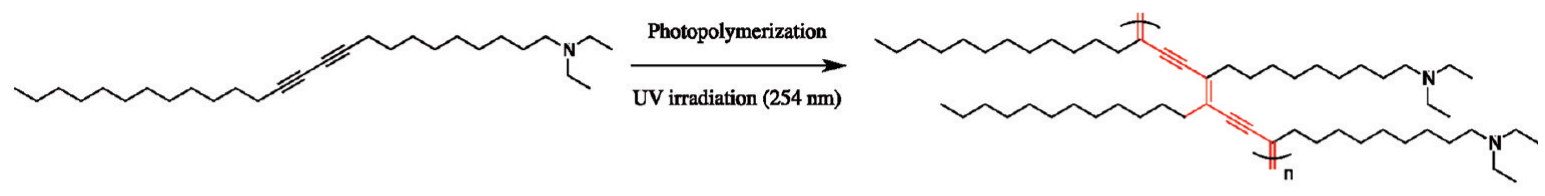

B

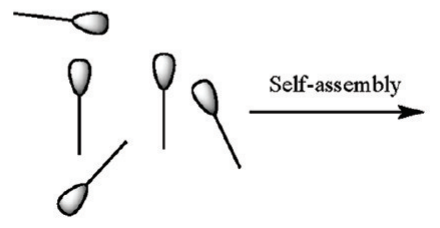

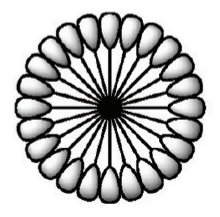

MNP

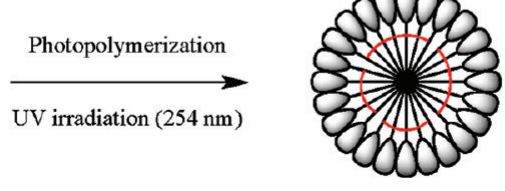

MP

Figure 2. (A) Amphiphile 4 and corresponding polymer formula. (B) Schematic process of polymerization. Polar head groups are shown as gray balls, amphiphile chains by straight gray lines, and polymeric chains by curved red lines. (MNP: nonpolymerized micelles. MP: polymerized micelles.)

(TEM) experiments, as shown in Figure 1A,D, where elongated and tubular structures are visible.

Micelle Polymerization. Diacetylene polymerization (Figure 2) was initiated by $254 \mathrm{~nm}$ ultraviolet irradiation. This process was followed over time by DLS and TEM experiments. As shown in Supporting Information, the sizes of the assemblies of compound 4 increase over polymerization time. Beyond one hour, photopolymerization deeply affects the size of the structures: after four hours, objects present a $40 \mathrm{~nm}$ diameter, which increases up to $250 \mathrm{~nm}$ after $7 \mathrm{~h}$. TEM only detected large aggregates. However, up to one hour of polymerization, assemblies kept the same diameter $(9 \mathrm{~nm})$ and still could be considered to be micelles $\left(\mathrm{M}_{4} \mathrm{P}_{1 \mathrm{~h}}\right)$. These small and spherical structures were also observed by TEM (Figure 1B), and as depicted in the Figure $1 \mathrm{E}$, the same results were obtained with micelles of compound 8 polymerized for $1 \mathrm{~h}\left(\mathrm{M}_{8} \mathrm{P}_{1 \mathrm{~h}}\right)$. The dilution of $\mathrm{M}_{4} \mathrm{P}_{1 \mathrm{~h}}$ micelles to $60 \mu \mathrm{M}$ in phosphate buffer (Figure 1C) did not destroy their structure, and this demonstrates their resistance to dilution and $\mathrm{pH}$ changes, and consequently the effectiveness of the polymerization.

The polymerization process was followed every ten minutes for up to $90 \mathrm{~min}$ by UV-visible spectroscopy (spectra available in Supporting Information) in order to analyze the propagation process. In both cases, ene-yne bond elongation was shown by a characteristic absorption band between 250 and $300 \mathrm{~nm}$. Its intensity increases over polymerization time and stabilizes at 20 min (Figure 3) showing an optimal propagation level into micelles. These analyses enabled us to choose the optimal condition taking into account self-assembly and micelle reticulation. For the rest of the study, photopolymerization time was one hour.

DNA Lipoplexes Characterization. Electrostatic interactions between plasmid DNA and nonpolymerized or polymerized micelles 
were imaged by agarose gel electrophoresis of lipoplexes, which were made with increasing $\mathrm{N} / \mathrm{P}$ (vector amine per DNA phosphate) ratios (Figure 4). The DNA was detected using ethidium bromide orange fluorescence.

$\mathrm{M}_{4} \mathrm{NP}$ lipoplexes in isotonic $150 \mathrm{mM} \mathrm{NaCl}$ showed full DNA condensation at $\mathrm{N} / \mathrm{P} 10$ and the corresponding polymerized lipoplexes at N/P 2. This notable improvement was also observed for $\mathrm{M}_{4}$ lipoplexes in iso-osmotic $5 \%$ glucose solutions in water. Thus, full DNA condensation was not observed with nonpolymerized lipoplexes in the range studied; however, it was observed at N/P 10 and above, for the polymerized lipoplexes.

A similar trend was observed for $\mathrm{M}_{8}$ lipoplexes. DNA condensation occurred at $\mathrm{N} / \mathrm{P} 2$ in isotonic $150 \mathrm{mM} \mathrm{NaCl}$ and for N/P 3 in iso-osmotic 5\% glucose solutions in water with

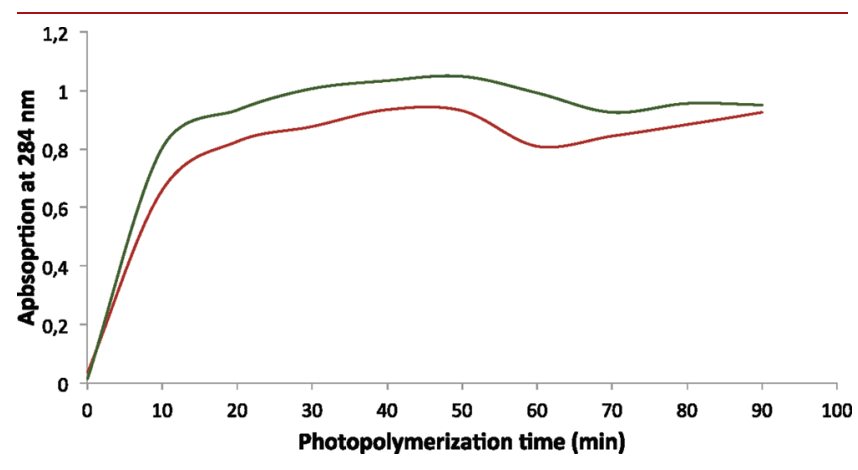

Figure 3. Absorption at $284 \mathrm{~nm}$ vs photopolymerization time. Green line: $\mathrm{M}_{4}$ solution. Red line: $\mathrm{M}_{8}$ solution. nonpolymerized lipoplexes. A slight improvement was observed with polymerized lipoplexes.

It is interesting to note that lipoplexes formulated in 5\% glucose solutions even these most compacted forms at high $\mathrm{N} / \mathrm{P}$ ratio remain accessible to ethidium bromide.

Lipoplexes prepared in 5\% glucose were further characterized by DLS. Size measurements on $\mathrm{M}_{4} \mathrm{P}_{1 \mathrm{~h}}$ lipoplexes (Figure 5A) showed that their diameter decreased when the $\mathrm{N} / \mathrm{P}$ ratio was increased. The same behavior was observed for $\mathrm{M}_{8} \mathrm{P}_{1 \mathrm{~h}}$ lipoplexes, except at N/P 20. Both formulations showed an average diameter of $45 \mathrm{~nm}$ at N/P 5, which was confirmed by TEM experiments (Figure 6A,C). Zeta $(\zeta)$ potential measurements made on the above lipoplexes showed increasing positive surface charges with $\mathrm{N} / \mathrm{P}$ ratio (Figures $5 \mathrm{~B}$ ). When prepared in $150 \mathrm{mM} \mathrm{NaCl}$, lipoplexes at N/P 5 became micrometric structures made of aggregated spheres (see Supporting Information).

Transfection of Cells in Culture. pCMV-Luc gene delivery experiments were conducted with $\mathrm{M}_{4}$ and $\mathrm{M}_{8}$ lipoplexes on HeLa cells, prepared either in $5 \%$ glucose (Figure $7 \mathrm{~A}$ ) or $150 \mathrm{mM} \mathrm{NaCl}$ solutions (see Supporting Information).

Final monomer concentrations in wells were calculated as described in Table 1. Final plasmid concentration was fixed to $2 \mu \mathrm{g} / \mathrm{mL}$.

In each case, the polymerized micelles exhibited higher transfection efficiency and lower toxicity than the nonpolymerized micelles.

N/P 5 was the optimal ratio for both $\mathrm{M}_{4} \mathrm{P}_{1 \mathrm{~h}}$ and $\mathrm{M}_{8} \mathrm{P}_{1 \mathrm{~h}}$, and they have the same level of luciferase expression, between $10^{10}$ and $10^{11} \mathrm{RLU} / \mathrm{mg}$ of protein. This level is 1 order of magnitude lower than the JetPEI system, which is considered a "gold standard"

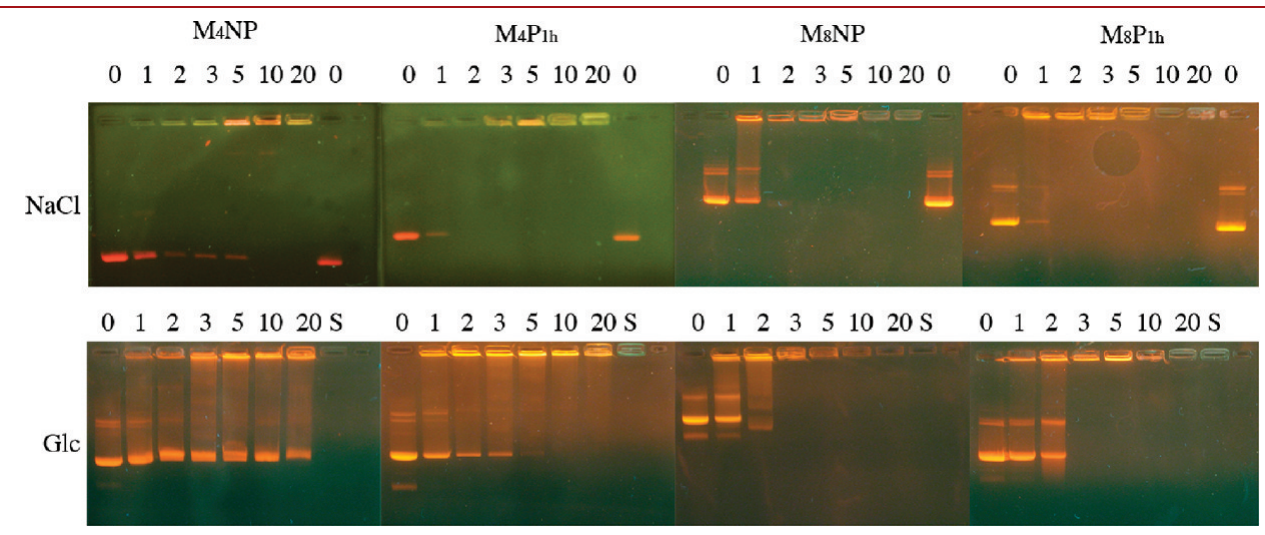

Figure 4. Agarose gels. Lipoplexes were prepared at N/P = 1 to 20; 0: pCMV-Luc without micelles; S: micelles without pCMV-Luc plasmid.

\begin{tabular}{l|cc}
$\mathrm{A}$ & & \\
$\mathrm{N} / \mathrm{P}$ & $\begin{array}{c}\mathrm{M}_{4} \mathrm{P}_{1 \mathrm{~h}} \\
(\mathrm{~nm})\end{array}$ & $\begin{array}{c}\mathrm{M}_{8} \mathrm{P}_{1 \mathrm{~h}} \\
(\mathrm{~nm})\end{array}$ \\
\hline 1 & 54 & 66 \\
2 & 43 & 49 \\
5 & 40 & 47 \\
20 & 24 & 90
\end{tabular}

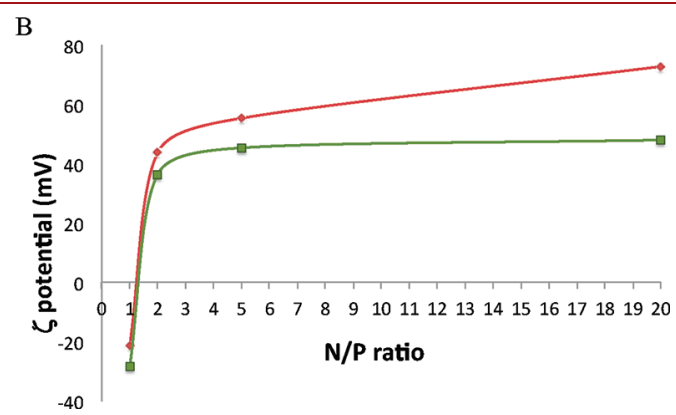

Figure 5. DLS results for M4P1h and M8P1h lipoplexes in 5\% glucose aqueous solution. A: diameters at various N/P ratios. B: Zeta potentials. Green line: $\mathrm{M}_{4} \mathrm{P}_{1 \mathrm{~h}}$ lipoplexes. Red line: $\mathrm{M}_{8} \mathrm{P}_{1 \mathrm{~h}}$ lipoplexes. 
in nonviral gene delivery; it is comparable to another commercially available gene delivery lipidic system, JetSi-ENDO, which is known for its high efficiency/toxicity ratio. However, $\mathrm{M}_{4} \mathrm{P}_{1 \mathrm{~h}}$ were found to be quite toxic, compared to $\mathrm{M}_{8} \mathrm{P}_{1 \mathrm{~h}}$ in optimal conditions. Transfection efficiencies were reduced by 1 to 3 orders of magnitude in the presence of $10 \%$ serum (see Figure 8 ), revealing deleterious interactions between the complexes and serum proteins. Thus, further developments (e.g., PEGylation and/or targeting ligands) will be necessary for effective in vivo gene delivery.

\section{DISCUSSION}

The application of polydiacetylene polymeric structures for gene delivery has never been studied. In a previous study, we have shown that amphiphiles formed by coupling diynic lipophilic tails and various polar headgroups spontaneously self-assembled into micelles in aqueous solution. In particular, coupling anionic, neutral, or cationic polar headgroups to 10,12-pentacosadiynoic acid led to amphiphiles with programmed $\mathrm{pH}$-dependent self-assembly

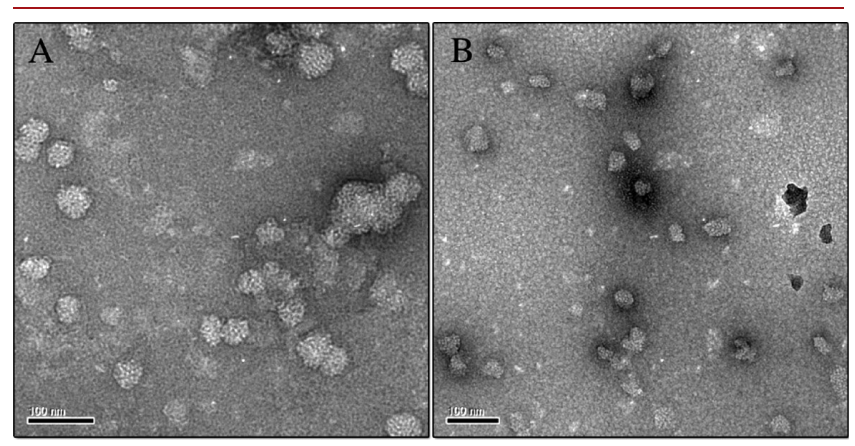

Figure 6. TEM images of micelles/pCMV-Luc lipoplexes at N/P 5 in water with $5 \%$ glucose. (A) $\mathrm{M}_{4} \mathrm{P}_{1 \mathrm{~h}} / \mathrm{pCMV}$-Luc lipoplexes. (B) $\mathrm{M}_{8} \mathrm{P}_{1 \mathrm{~h}} /$ pCMV-Luc lipoplexes. Scale bars: $100 \mathrm{~nm}$. properties. ${ }^{25}$ On the other hand, when we varied the length of the hydrophobic chain length containing a neutral polar headgroup, we found that, while 12 carbon chain was too short to enable the formation of micelles, 18 and 25 carbon chains led to stable micelles with CMC of $0.091 \mathrm{mg} / \mathrm{mL}$ and $0.082 \mathrm{mg} / \mathrm{mL}$, respectively (unpublished results). Since it appears to form robust micelles and is readily available, we decided to use 10,12-pentacosadiynoic acid $\left(\mathrm{C}_{25}\right)$ as a lipophilic tail for this study. Cationic monomers were easily synthetized from PCDA and, as expected, selfassembled into micelles in a simple and spontaneous process. It is interesting to note that $\mathrm{pH}$ and medium composition are important parameters for micelle formation.

The photopolymerization state requires a perfectly calibrated process to ensure the size reproducibility of the polymerized micelle. Elongation creates covalent cross-linking between monomers into micelles to provide a three-dimensional network and more rigid assemblies as shown in Figure 1B. However, DLS experiments showed that, beyond one hour, polymerization provides larger aggregates than the initial micelles. This fact has already been observed in micelle polymerization ${ }^{26}$ and in this study could be explained by geometric constraints imposed by the ene-yne backbone. It is well-known that photopolymerization of diacetylene groups occurs only in a highly ordered state. ${ }^{16}$ In our case, the propagation of ene-yne bonds strongly alters the initial morphology, resulting in larger structures with lower radii of curvature.

Micelle structures were observed by DLS and TEM over one hour of polymerization, and UV spectrophotometric analysis showed a good level of elongation. One hour of polymerization

Table 1. $M_{4}$ and $M_{8}$ Monomer Concentrations for Transfection Assays

$\begin{array}{cccrcccc}\mathrm{N} / \text { P ratio } & 0 & 1 & 2 & 3 & 5 & 10 & 20 \\ \mathrm{M}_{4}(\mu \mathrm{M}) & 0 & 6.1 & 12.1 & 18.2 & 30.3 & 60.7 & 121.3 \\ \mathrm{M}_{8}(\mu \mathrm{M}) & 0 & 2.0 & 4.0 & 6.1 & 10.1 & 20.2 & 40.3\end{array}$

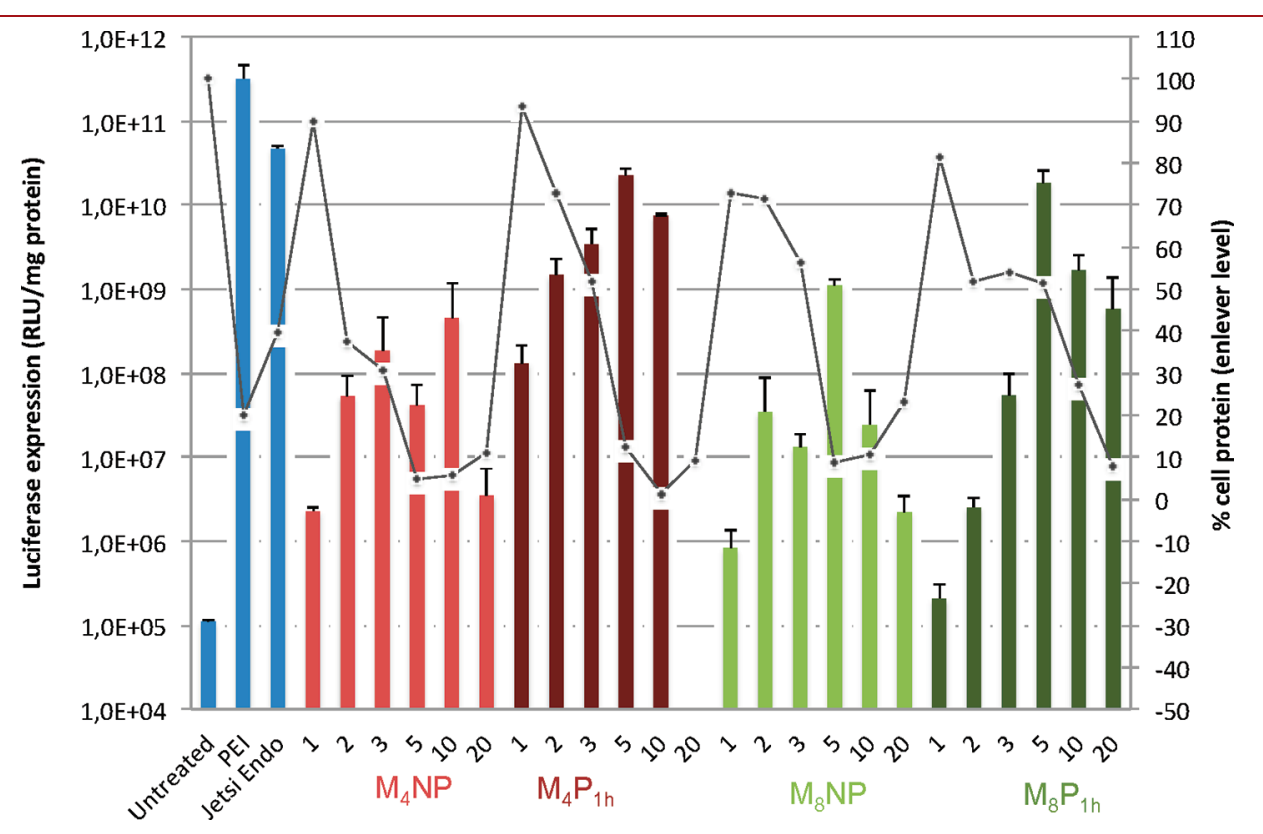

Figure 7. Gene delivery experiments of pCMV-Luc at various N/P (lipoplexes prepared in 5\% glucose solution), without serum. Luciferase expression (bars) and percentage of total cellular proteins (line and circles) are given for negative control (untreated), positive control (JetPEI and JetSi-ENDO), $\mathrm{M}_{4} \mathrm{NP}$ (light red), $\mathrm{M}_{4} \mathrm{P}_{1 \mathrm{~h}}$ (dark red), $\mathrm{M}_{8} \mathrm{NP}$ (light green), and $\mathrm{M}_{8} \mathrm{P}_{1 \mathrm{~h}}$ (dark green). Means and sd of separate triplicates are given. 


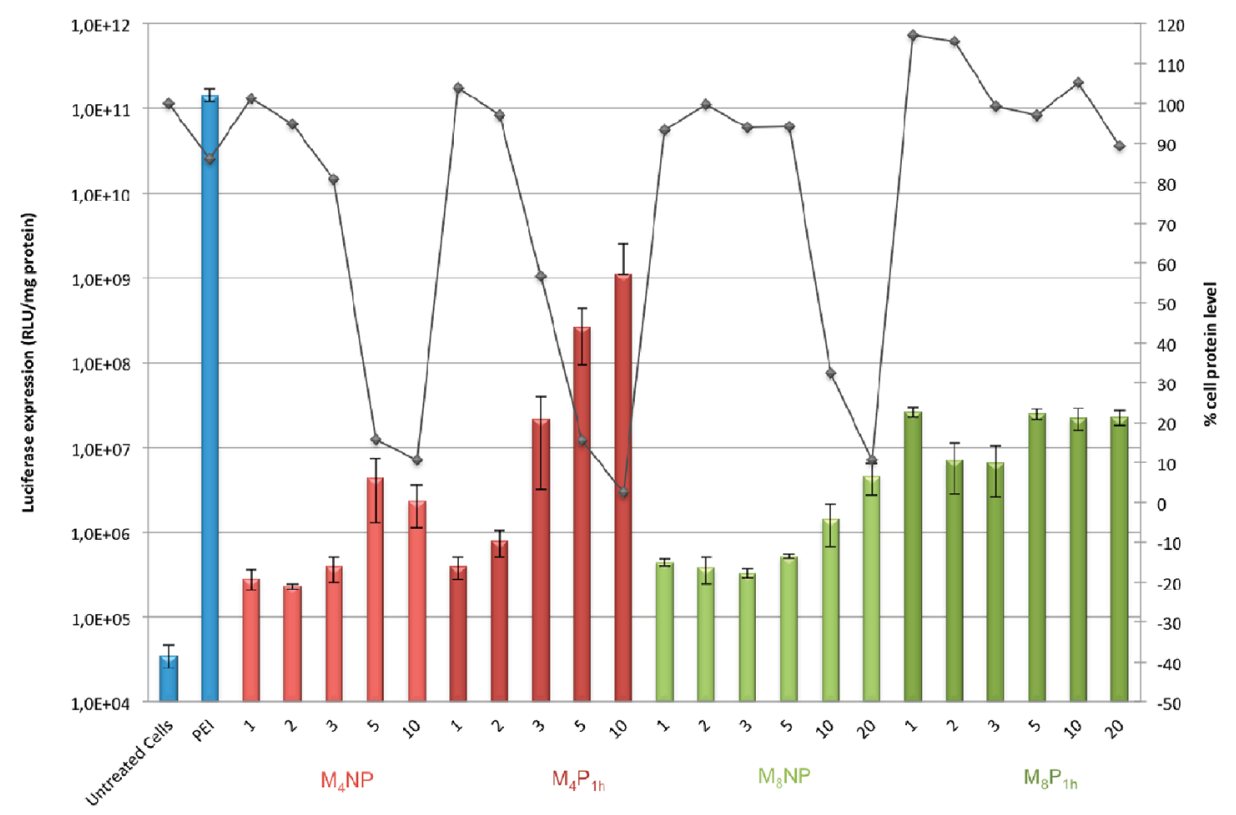

Figure 8. Gene delivery experiments of pCMV-Luc at various N/P (lipoplexes prepared in 5\% glucose solution), with serum. Luciferase expression (bars) and percentage of total cellular proteins (line and circles) are given for negative control (untreated), positive control (JetPEI), $\mathrm{M}_{4} \mathrm{NP}$ (light red), $\mathrm{M}_{4} \mathrm{P}_{1 \mathrm{~h}}$ (dark red), $\mathrm{M}_{8} \mathrm{NP}$ (light green), and $\mathrm{M}_{8} \mathrm{P}_{1 \mathrm{~h}}$ (dark green). Means and sd of separate triplicates are given.

seemed to be the best compromise to retain the original structure, while having enough cross-linking to "freeze" the micelles. Diluting the micelles below their CMC in phosphate buffer $(\mathrm{pH}=7)$ proved the efficiency of polymerization. Indeed, polymerized micelles were still observed after switching to neutral conditions, whereas nonpolymerized micelles were disrupted.

Agarose gel electrophoresis experiments showed the different behaviors of polymerized and nonpolymerized lipoplexes. Using either $\mathrm{M}_{4}$ or $\mathrm{M}_{8}$ complexes, the polymerized lipoplexes show full DNA condensation at lower $\mathrm{N} / \mathrm{P}$ ratio than nonpolymerized lipoplexes. In polymerized micelles, the exchange of monomers between the micelle and its surroundings was strongly inhibited, and led to better DNA condensation and lipoplex stability. In isotonic $150 \mathrm{mM} \mathrm{NaCl}$ for $\mathrm{N} / \mathrm{P} 20$, no fluorescence due to the ethidium bromide staining was observed, reflecting very good DNA compaction into the lipoplexes. It has to be noted that polymerized micelles have their own green fluorescence, due to ene-yne bonds, which is absent in nonpolymerized micelles.

Lipoplexes were observed by DLS experiments in iso-osmotic $5 \%$ glucose solutions in water. A previous study showed that lipoplexes containing a single pCMV-Luc plasmid molecule have a size of about $25 \mathrm{~nm} .{ }^{27}$ In our case, size measurements, confirmed by TEM experiments, showed very small structures of about $40 \mathrm{~nm}$, containing probably two to four plasmid molecules. This would allow further development of the lipoplexes for in vivo gene delivery because the size range should permit good tissue distribution.

In vitro transfection results showed that gene transfection potency is improved by photopolymerization, and as observed for agarose gel electrophoresis experiments, the best results are obtained for N/P 5, especially for $\mathrm{M}_{8}$, which is considerably less toxic than $\mathrm{M}_{4}$. This is expected since, at any given $\mathrm{N} / \mathrm{P}$ ratio, the triamine $\mathrm{M}_{8}$ concentration is only one-third of the monoamine $\mathrm{M}_{4}$ concentration. At the optimal $\mathrm{N} / \mathrm{P}$ ratio in $5 \%$ glucose solution, $\mathrm{M}_{4} \mathrm{P}_{1 \mathrm{~h}}$ and $\mathrm{M}_{8} \mathrm{P}_{1 \mathrm{~h}}$ transfection efficiencies are comparable, in serum-free serum conditions, to that of JetSi-ENDO, a cationic lipid transfection reagent. Synthesis of new amphiphilic molecules designed to be more effective for in vivo use, with poly(ethylene glycol) groups and targeting ligands, for example, should improve the robustness of our system.

In summary, we have prepared new cationic polydiacetylene micelles, with a reasonable in vitro gene transfection efficiency, and shown that photopolymerization significantly improves their transfection potency. These micelles are small, and their modular structure could lead to further developments. The use of functionalizable polar headgroups, for example, could allow addition of targeting ligands and/or poly(ethylene glycol). Alkyne polar headgroup could also lead to postfunctionalization by clickchemistry.

\section{ASSOCIATED CONTENT}

S Supporting Information. Characterization and NMR spectra of compounds, UV/visible spectra, DLS experiments, TEM images and gene transfer experiments. This material is available free of charge via the Internet at http://pubs.acs.org.

\section{AUTHOR INFORMATION}

\section{Corresponding Author}

*remy@bioorga.u-strasbg.fr, wagner@bioorga.u-strasbg.fr.

\section{ACKNOWLEDGMENT}

We thank Christine Ruhlmann from the Structural Biology and Genomics Department of IGBMC for her help with TEM. E.M. received a grant from MESR.

\section{REFERENCES}

(1) Shimizu, T., Masuda, M., and Minamikawa, H. (2005) Supramolecular nanotube architectures based on amphiphilic molecules. Chem. Rev. 105, 1401-1444. 
(2) Fuhrhop, J.-H., and Wang, T. (2004) Bolaamphiphiles. Chem. Rev 104, 2901-2938.

(3) Morin, E., Guenet, J.-M., Diaaz, D. D., Remy, J.-S., and Wagner, A. (2010) Fine-tuning the morphology of self-assembled nanostructures of propargyl ammonium-based amphiphiles. J. Phys. Chem. B 114, 12495-12500.

(4) Douliez, J.-P. (2005) Self-assembly of hollow cones in a bola-amphiphile/hexadiamine salt solution. J. Am. Chem. Soc. 127, 15694-15695.

(5) Richard, C., Balavoine, F., Schultz, P., Ebbesen, T. W., and Mioskowski, C. (2003) Supramolecular self-assembly of lipid derivatives on carbon nanotubes. Science 300, 775-778.

(6) Lasic, D. D., and Templeton, N. S. (1996) Liposomes in gene therapy. Adv. Drug Delivery Rev. 20, 221-266.

(7) Miller, A. D. (1998) Cationic liposomes for gene therapy. Angew. Chem., Int. Ed. 37, 1768-1785.

(8) Dauty, E., Remy, J.-S., Blessing, T., and Behr, J.-P. (2001) Dimerizable cationic detergents with a low $\mathrm{cmc}$ condense plasmid DNA into nanometric particles and transfect cells in culture. J. Am. Chem. Soc. 123, 9227-9234.

(9) Behr, J. P. (1993) Synthetic gene-transfer vectors. Acc. Chem. Res. 26, 274-278.

(10) Wong, F. M. P., Reimer, D. L., and Bally, M. B. (1996) Cationic lipid binding to DNA: characterization of complex formation. Biochemistry 35, 5756-5763.

(11) Zuidam, N. J., and Barenholz, Y. (1998) Electrostatic and structural properties of complexes involving plasmid DNA and cationic lipids commonly used for gene delivery. Biochim. Biophys. Acta 1368, $115-128$.

(12) Durairaj, B., and Blum, F. D. (1989) Synthesis and dynamics of oligomeric micelles. Langmuir 5, 370-372.

(13) Cochin, D., Candau, F., and Zana, R. (1993) Photopolymerization of micelle-forming monomers. 1. Characterization of the systems before and after polymerization. Macromolecules 26, 5755-5764.

(14) Tomatsu, I., Hashidzume, A., and Harada, A. (2009) Photopolymerization of amphiphilic N,O-diacylated serine-based monomers in their micellar states for an encapsulation. Macromol. Chem. Phys. $210,1640-1646$.

(15) O'Reilly, R. K., Hawker, C. J., and Wooley, K. L. (2006) Crosslinked block copolymer micelles: functional nanostructures of great potential and versatility. Chem. Soc. Rev. 35, 1068-1083.

(16) Zhou, W., Li, Y., and Zhu, D. (2007) Progress in polydiacetylene nanowires by self-assembly and selfpolymerization. Chem. Asian J. 2, 222-229.

(17) Thauvin, C., Rickling, S., Schultz, P., Celia, H., Meunier, S., and Mioskowski, C. (2008) Carbon nanotubes as templates for polymerized lipid assemblies. Nat. Nanotechnol. 3, 743-748.

(18) Lee, J., Jun, H., and Kim, J. (2009) Polydiacetylene-liposome microarrays for selective and sensitive mercury(II) detection. Adv. Mater. 21, 3674-3677.

(19) Lee, J., Kim, H.-J., and Kim, J. (2008) Polydiacetylene liposome arrays for selective potassium detection. J. Am. Chem. Soc. 130, 5010-5011.

(20) Sarkar, A., Okada, S., Matsuzawa, H., Matsuda, H., and Nakanishi, H. (2000) Novel polydiacetylenes for optical materials: beyond the conventional polydiacetylenes. J. Mater. Chem. 10, 819-828.

(21) Perino, A., Klymchenko, A., Morere, A., Contal, E., Rameau, A., Guenet, J.-M., Mély, Y., and Wagner, A. (2011) Structure and behavior of polydiacetylene-based micelles. Macromol. Chem. Phys. 212, 111-117.

(22) FR0802390. (2008), Les Laboratoires Servier et Commissariat à l'Energie Atomique, invs.: Ogier, J., Doris, E., Lefoulon, F., and Thomas, A.

(23) Patel, M., Vivien, E., Hauchecorne, M., Oudrhiri, N., Ramasawmy, R., Vigneron, J.-P., Lehn, P., and Lehn, J.-M. (2001) Efficient gene transfection by bisguanylated diacetylene lipid formulations. Biochem. Biophys. Res. Commun. 281, 536-543.

(24) Yu, G. S., Choi, H., Bae, Y. M., Kim, J., and Choi, J. S. (2008) Preparation of cationic polydiacetylene nanovesicles for in vitro gene delivery. J. Nanosci. Nanotechnol. 8, 5266-5270.
(25) Thauvin, C., Perino, A., Contal, E., Morin, E., Schultz, P., Meunier, S., and Wagner, A. (2011) Programmed dispersions of MWNTs in aqueous media by coating with photopolymerizable synthetic amphiphiles. J. Phys. Chem. C 115, 7319-7322.

(26) Tajima, K., and Aida, T. (2000) Controlled polymerizations with constrained geometries. Chem. Commun. 2399-2412.

(27) Blessing, T., Remy, J.-S., and Behr, J.-P. (1998) Monomolecular collapse of plasmid DNA into stable virus-like particles. Proc. Natl. Acad. Sci.U.S.A. 95, 1427-1431. 